вчителя інформатики. Перспективи подальшого дослідження вбачаємо в розробленні дидактичних матеріалів з курсу лінійної алгебри на основі компетентнісного підходу.

\title{
Література
}

1. Монахов В. М. Компетентностно-контекстный формат обучения и проектирование образовательных модулей / $\mathrm{B.} \mathrm{М.} \mathrm{Монахов//} \mathrm{Вестник} \mathrm{МггУ}$ им. М. А. Шолохова. Сер. «Педагогика и психология». - 2012. - № 1. - С. 49-60. 2. Постанова Кабінету Міністрів України від 23 листопада 2011 р. № 1392 Про затвердження Державного стандарту базової і повної загальної середньої освіти. - К., 2011. - $100 \mathrm{c}$.

\section{МЕТОДОЛОГІЧНІ ПІДХОДИ ДО РОЗВ'ЯЗАННЯ ПРОБЛЕМИ ФОРМУВАННЯ САМОСТІЙНО-ПІЗНАВАЛЬНОЇ ДІЯЛЬНОСТІ СТУДЕНТІВ}

Бондаревська О. М. Методологічні підходи до розв'язання проблеми формування самостійно-пізнавальної діяльності студентів.

У статті розглядається проблема організації самостійно-пізнавальної діяльності студентів, аналізуються методологічні підходи до розв'язання проблеми формування самостійно-пізнавальної діяльності студентів, визначено роль самостійнопізнавальної діяльності у професійному становленні майбутнього фахівця.

Ключові слова: самостійно-пізнавальна діяльність, діяльнісний підхід, особистісно-діяльнісний підхід, індивідуальний підхід, системний підхід, ресурсний підхід, компетентнісний підхід.

Бондаревская Е. М. Методологические подходы к решению проблемы формирования самостоятельно-познавательной деятельности студентов.

В статье рассматривается проблема организации самостоятельно-познавательной деятельности студентов, анализируются методологические подходы к решению проблемы формирования самостоятельно-познавательной деятельности студентов, определена роль самостоятельно-познавательной деятельности в профессиональном становлении будущего специалиста.

Ключевые слова: самостоятельно-познавательная деятельность, деятельностный подход, личностно-деятельностный подход, индивидуальный подход, системный подход, ресурсный подход, компетентностный подход.

Bondarevskaya E. O. Methodological approaches to solving the problem of the students' independent-cognitive activities forming.

The article considers the problem of the students' independent-cognitive activities forming, the analysis of the methodological approaches to solving the problem of the students' independent-cognitive activities forming is carried out, the role of the students' independent-cognitive activity in the professional formation of the future specialist is defined.

Key words: independent-cognitive activity, activity approach, personal-activity approach, individual approach, system approach, resource approach, competence approach.

В умовах стрімкого розвитку сучасної цивілізації система вищої освіти повинна підготувати майбутнього фахівця, здатного до саморозвитку та самоосвіти. Самостійнопізнавальна діяльність того, хто навчається, постає визначальною характеристикою якості 
освіти, тому нині особливої значущості набуває проблема ефективної організації самостійно-пізнавальної діяльності студентів. Приєднання України до Болонської декларації зумовлює необхідність створення у ВНЗ системи самостійної роботи студентів, що забезпечує засвоєння ними змісту навчання та набуття ними професійної компетентності. Така система повинна створити умови, що будуть спонукати студентів до самостійного пошуку, саморозвитку, самовдосконалення та індивідуальної творчої роботи. Організація самостійно-пізнавальної діяльності студентів залежить від використаного підходу до процесу навчання.

Метою роботи є аналіз підходів сучасних науковців до визначення поняття самостійно-пізнавальної діяльності студентів.

Наукове обговорення феномена самостійно-пізнавальної діяльності студентів протягом багатьох років належить до предмета досліджень таких наук, як педагогіка i когнітивна психологія. Особливої уваги ця тема набула на початку сімдесятих років, як відмова від біхевіористської моделі та одночасне звернення до когнітивного та соціально-когнітивного підходів [7].

Протягом багатьох років здійснено 3 різних позицій низку досліджень різноманітних концепцій та запропоновано визначення дефініції самостійнопізнавальної діяльності студентів. Так, у літературі, зокрема, спостерігаємо такі терміни, як самостійне, саморегульоване, самостійно контрольоване, самоорганізоване, автономне, аутодидактичне, відкрите, самовизначене та незалежне навчання. Різні визначення залишаються взаємозамінюваними для різноманітних сутностей та акцентів розгляду самостійного навчального процесу, у якому той, хто навчається, «приймає істотні рішення з приводу того, що, коли, як та у якій послідовності він вивчатиме, а також наскільки вагомим буде вплив та його наслідки» [7, с. 238].

У педагогічній науці виокремились різні підходи до тлумачення самостійнопізнавальної діяльності студентів. 3 аналізу психолого-педагогічної та методичної літератури можна виокремити такі: діяльнісний підхід, особистісно-діяльнісний підхід, соціально-когнітивний, феноменологічний, когнітивно-конструктивістський підхід, індивідуальний підхід, системний підхід, ресурсний підхід, компетентнісний підхід.

Філософський словник визначає підхід «як комплекс парадигматичних, синтагматичних і прагматичних структур і механізмів у пізнанні та / або практиці, що характеризує конкуруючі між собою (або історично змінюють один одного) стратегії і програми у філософії, науці, політиці чи в організації життя і діяльності людей» [6].

Усі підходи об'єднує те, що вони мають справу з явищами самосприйняття, самоефективністі, а також свідомого управління процесами міркування, навчання та розв'язання проблем, тобто самоконтролем з різноманітним оцінюванням. Деякі з цих підходів забезпечили базову підставу для подальшого обговорення сфери навчальних стратегій i, отже, будуть обговорюватися більш детально далі.

Досліджуючи проблему самостійно-пізнавальної діяльності студента передовсім необхідно звернути увагу на діяльнісний підхід. Саме діяльнісне спрямування цієї категорії зумовлює прагнення використати положення теорії діяльності в методиці та інтерпретації змісту самостійно-пізнавальної діяльності студентів. Згідно 3 постановою Кабінету Міністрів України «Про затвердження Державного стандарту базової і повної загальної середньої освіти» «діяльнісний підхід- спрямованість навчально-виховного процесу на розвиток умінь і навичок особистості, застосування на практиці здобутих знань 3 різних навчальних предметів, успішну адаптацію людини в соціумі, професійну самореалізацію, формування здібностей до колективної 
діяльності та самоосвіти» [2].

Завдяки діяльнісному підходу досліджується реальний процес взаємодії людини 3 навколишнім світом, цей зв'язок забезпечує розв'язання певних важливих завдань. Діяльнісний підхід спрямований на організацію діяльності того, хто навчається, так, щоб він був активним у пізнанні, праці, спілкуванні, своєму розвитку.

Основні представники особистісно-діяльнісного підходу в психології (Л. Виготський, О. Леонтьєв, С. Рубінштейн) розглядають особистість як суб'єкт діяльності, який, самостійно формуючись у діяльності та у спілкуванні 3 іншими людьми, визначає характер цієї діяльності та спілкування $[1 ; 3 ; 5]$. Особистісний компонент цього підходу грунтується на природньому процесі саморозвитку здібностей, самовизначення, самореалізації, самоствердження, створення для цього відповідних умов. У процесі формування самостійно-пізнавальної діяльності у студентів викладач повинен розвивати їх позитивну мотивацію, інтелектуальні здібності, закладати основи для самоосвіти, самовдосконалення, саморозвитку. Людина стає справжнім суб'єктом свого життя та перебудовує власну життєдіяльність на предмет практичного перетворення, займаючись саморозвитком.

У центрі уваги феноменологічного підходу знаходяться процеси самосприйняття, самооцінки як основи для самоконтролю і саморегуляції. Основна увага цього підходу спрямована на вивчення власних потреб, цінностей та інтересів, а також на створення образу себе як активної, автономної особи, що діє. 3 феноменологічної точки зору ясно, що розвиток і створення саморегульованих навичок розвитку та усвідомлення власної «я-системи» залежить від багатьох чинників. До того ж усвідомлення студентом відповідальності за розвиток свого «я», а також за результати навчального процесу вважається фундаментальним у регулюванні навчальної поведінки.

Соціально-когнітивний підхід до саморегульованого навчання заснований на соціально-когнітивній навчальній теорії. Ключовими аспектами цього підходу $\epsilon$ сприйняття самоефективності особистості, очікування наслідків дій, а також навчання за моделлю. Модель людських дій базується на основі так званої взаємодії трьох компонентів:

- зміни навчального оточення;

- пізнавальні та особистісні чинники індивіда;

- поведінка індивіда.

Когнітивно-конструктивістський підхід виходять 3 того, що студенти будують свої теорії про самостійні компетенції, про явище зусилля, про властивості задач, а також про стратегії навчання у процесі їх шкільного розвитку. Ці окремі аспекти теорії вдосконалювались у процесі розвитку і поступово інтегрували в суміжну теорію саморегульованого навчання, яка потім почала служити як орієнтир для оптимізації роботи.

Індивідуальний підхід у педагогічній теорії та практиці визнаний як один із провідних. Цей підхід доцільно розглядати як педагогічний принцип, що сприяє більш глибокому й повному баченню, розумінню індивідуальності того, хто навчається, і на цій основі - його гармонійному розвитку. Результативне здійснення індивідуального підходу вимагає глибокого вивчення особистості, іiі діяльності та індивідуальних особливостей. Важливе значення для здійснення індивідуального підходу має визначення найближчих конкретних і більш віддалених цілей, а також формування індивідуальної стратегї̈ самостійно-пізнавальної діяльності студента.

Самостійно-пізнавальна діяльність студентів $\epsilon$ складною системою взаємопов'язаних компонентів, які утворюють єдину цілісність, підпорядковану цілям 
освіти й розвитку. Так, з точки зору системного підходу, сучасні науковці, зокрема В. Козаков, визначають самостійно-пізнавальну діяльність студентів «як систему заходів, спрямованих на виховання активності й самостійності як рис особистості, набуття вмінь i навичок раціонального отримання корисної інформації опосередковано через зміст і методи всіх видів навчальних занять» [2].

Нині психолого-педагогічна наука все частіше використовує такі категорії, як «ресурсний підхід», «особистісний ресурс», які орієнтують на розуміння особистості, що самостійно розвивається та вимагає необхідних умов для розкриття закладеного в ній потенціалу. Ресурсний підхід відкриває широкі можливості у плані формування індивідуальної стратегії самостійно-пізнавальної діяльності студентів. Особливий науковий інтерес 3 психолого-педагогічної точки зору до вивчення особистісного ресурсу розвитку пояснюється, на наш погляд, усвідомленням реальної можливості через використання означеної категорії оцінювати результативність застосування моделі формування індивідуальної стратегії самостійно-пізнавальної діяльності студентів та дидактичних умов, що забезпечують їі впровадження.

Застосування компетентісного підходу під час організації та здійснення самостійно-пізнавальної діяльності студентів $\epsilon$ надзвичайно важливим, оскільки відповідно до Європейського освітнього контексту компетенції передбачають сформованість знань як розуміння, знання як дії, знання як буття. 3 позиції психологопедагогічної науки компетентнісний підхід - це спрямованість педагогічного процесу на формування i розвиток ключових (базових, основних) i предметних компетентностей особистості. У результаті буде сформована загальна компетенція людини - інтегрована характеристика особистості.

Аналіз методологічних підходів до розв'язання проблеми самостійно-пізнавальної діяльності студентів, переконує в необхідності подальшого розроблення діяльнісного та особистісно-діяльнісного підходів. Удаючись до грунтовного аналізу поняття «самостійно-пізнавальна діяльність студентів» не менш доцільним буде скористатися іншими підходами, зокрема, соціально-когнітивним, феноменологічним, когнітивноконструктивістським, індивідуальним, системним, ресурсним та компетентнісним, що, доповнюючи один одного, розкривають сутність поняття.

\section{Література}

1. Выготский Л. С. Педагогическая психология / Лев Семенович Выготский: [под ред. В. В. Давыдова]. - М. : Педагогика, 1991. - 479 с. 2. Козаков В. А. Самостоятельная работа студентов и ее информационно-методическое обеспечение / Виталий Андреевич Козаков. - К. : Вища школа, 1990. - 248 с. 3. Леонтьев А. Н. Деятельность. Сознание. Личность / Алексей Николаевич Леонтьев. - М. : Политиздат, 1977. - 303 с. 4. Постанова Кабінету Міністрів України «Про затвердження Державного стандарту базової і повної загальної середньої освіти» (Державний стандарт, розд. 1) від 23 листопада 2011 р. № 1392 (див. текст) м. Київ. 5. Рубинштейн С. Л. Проблемы общей психологии / Сергей Львович Рубинштейн. М. : Педагогика, 1973. - 423 с. 6. Философский словарь / [под ред. И. Т. Фролова]. [6-е изд., перераб. и доп.]. - М. : Политиздат, 1991. - 560 с. 7. Fridrich Н. F. Psychologische Aspekte autodidaktischen Lernens. In: Unterrischtswissenschaft, Heft 3./ H. F. Fridrich. - Weinheim, Juventa. - S. 197-218. 